\title{
Erratum to: Left laparoscopic paraduodenal hernia repair
}

\author{
Abed Khalaileh - Avraham Schlager - Miklosh Bala • \\ Samir Abu-Gazala • Ram Elazary • Avraham I. Rivkind • \\ Yoav Mintz
}

Published online: 30 December 2011

(C) Springer Science+Business Media, LLC 2011

Erratum to: Surg Endosc (2010) 24:1486-1489

DOI 10.1007/s00464-009-0794-7

The fourth author's name was published incorrectly.

The corrected name appears in this erratum.

The online version of the original article can be found under doi:10.1007/s00464-009-0794-7.
A. Khalaileh $(\bowtie) \cdot$ M. Bala $\cdot$ S. Abu-Gazala $\cdot$ R. Elazary .
A. I. Rivkind · Y. Mintz
Department of Surgery, Hadassah Hebrew University Medical
Center, Kiryat Hadassah, P.O.B. 12000, 91120 Jerusalem, Israel
e-mail: Abedk@ekmd.huji.ac.il

A. Schlager

Department of Surgery, New York University Hospital,

New York, NY, USA 